\title{
Selenium and Health: An Update on the Situation in the Middle East and North Africa
}

\author{
Sohayla A. Z. Ibrahim ${ }^{1}$, Abdelhamid Kerkadi ${ }^{2}$ and Abdelali Agouni ${ }^{1, *(1)}$ \\ 1 Department of Pharmaceutical Sciences, College of Pharmacy, QU health, Qatar University, P.O. Box 2713, \\ Doha, Qatar \\ 2 Department of Nutrition, College of Health Sciences, QU health, Qatar University, P.O. Box 2713, Doha, Qatar \\ * Correspondence: aagouni@qu.edu.qa; Tel.: +974-4403-5610
}

Received: 29 May 2019; Accepted: 19 June 2019; Published: 27 June 2019

check for updates

\begin{abstract}
Selenium (Se) is an important trace element that should be present in the diet of all age groups to provide an adequate intake. Se is incorporated in 25 known selenoproteins, which mediate the biological effects of Se including, immune response regulation, maintenance of thyroid function, antioxidant defense, and anti-inflammatory actions. A balanced intake of Se is critical to achieve health benefits because depending on its status, Se has been found to play physiological roles or contribute to the pathophysiology of various diseases including, neurodegenerative diseases, diabetes, cancer, and cardiovascular disorders. Se status and intake are very important to be known for a specific population as the levels of Se are highly variable among different populations and regions. In the Middle East and North African (MENA) region, very little is known about the status of Se. Studies available show that Se status is widely variable with some countries being deficient, some over sufficient, and some sufficient. This variability was apparent even within the same country between regions. In this review, we summarized the key roles of Se in health and disease and discussed the available data on Se status and intake among countries of the MENA region.
\end{abstract}

Keywords: selenium; chronic diseases; Middle East; North Africa

\section{Introduction}

Selenium (Se) is a semi-solid metal that was discovered in 1817 as a byproduct of sulphuric acid synthesis. It belongs to group 6 of the periodic table with an atomic number of 34 . It is a red colored powder; however, in vitreous form it is observed as black, and in crystalline form it is observed as metallic gray. Se exists in many different oxidation states including $2+, 4+, 6+$, and 2- [1]. Se is present in small amounts in food mostly in organic forms (selenomethionine and selenocysteine) and rarely in inorganic forms (selenate and selenite) [2]. Selenomethionine is usually derived from animal sources in addition to cereal products grown in areas where the soil is rich in Se whereas selenocysteine is only obtained from animal sources [3]. Inorganic forms are the major sources of Se incorporated into dietary supplements [2]. Se concentrations in the soil where plants are grown or where animals are raised are important indicators of Se intake in a country leading to tremendous variations among different countries in Se status [2,4]. The most common sources of Se are Brazil nuts, cereals, offal, fish, eggs, poultry, and vegetables [3-5].

Se is a necessary trace element that should be present in the diet of all age groups. The Recommended Dietary Allowance (RDA) of Se is generally based on the optimum amount that can maximize the activity of selenoprotein glutathione peroxidase [2-4]. This value was estimated to be $55 \mu \mathrm{g} /$ day for both males and females [2-4,6]. The Estimated Average Requirement (EAR) was found to be around $45 \mu \mathrm{g} /$ day for 19-50-year-old men and women and the tolerable upper intake level (UL) is around $400 \mu \mathrm{g} /$ day $[3,4]$. However, the optimal amount required to achieve maximum health 
benefits is unknown [3]. The World Health Organization (WHO) recommends that the optimum serum concentration of Se for healthy adults is $39.5-194.5 \mathrm{ng} / \mathrm{ml}$ and that the concentration that maximizes glutathione peroxidase activity is between 70 and $90 \mathrm{ng} / \mathrm{ml}[7,8]$.

Very limited data exist on Se toxicity in humans; however, animal studies are available on chronic Se poisoning [4]. It was reported that an intake of around $800 \mu \mathrm{g} /$ day of Se would cause no observed adverse effect level (NOAEL), 1,540 to 1,600 $\mu \mathrm{g}$ /day of Se would result in low observed adverse effect level (LOAEL) and 5,000 $\mu \mathrm{g} /$ day of Se is the toxic level where selenosis is expected to happen [3]. LOAEL is associated with symptoms of hair and nail brittleness and loss, garlic like breath odor, gastrointestinal disturbances, and fatigue [3,4]. Selenosis can be associated with serious respiratory, renal, and cardiac complications [3].

Se status can be assessed through blood, urine, nails, and hair levels. Blood specimens can be either whole blood, erythrocytes, serum, or plasma. Erythrocytes, hair, and nails reflect long-term status opposing to plasma or serum which reflect short-term levels. It is challenging to compare Se levels across different countries due to the wide variations in methodologies of Se detection among different laboratories $[9,10]$.

\section{Selenium: A Focus on Biology}

\subsection{Selenoproteins as Mediators of Se Actions}

Se is an essential nutrient to human biology. The beneficial roles of Se to human health and its requirement for life have been known for several decades. Se exists in 25 known selenoproteins, some of which have important known biological functions [11]. The critical role of Se in human health is particularly underscored by being the sole trace element specified in the genetic code as selenocysteine, today recognized as the 21st amino acid, which has its proper genetic code, specific biosynthesis pathway, and insertion mechanism. This amino acid exists in the active site of many selenium-dependent enzymes that are responsible for multiple essential functions in the human body $[1,12,13]$. In this case, Se acts as a redox center. For example, thioredoxin reductase, a selenoenzyme, participates in DNA synthesis by reducing nucleotides which then helps in controlling the redox state intracellularly [3]. Another example is iodothyronine deiodinases which activates thyroid hormone [1]. Other selenoproteins have different functions including anti-inflammatory and antioxidant effects; however, some of those functions are yet to be identified. The biological effects of Se also include its participation in immune responses and thyroid function whereas its serum level can also be linked with risk of diabetes, cardiovascular disease (CVD), and cancer [5]. Table 1 summarizes the main functions and significance of the different known selenoproteins.

Table 1. Functions and significance of selenoproteins

\begin{tabular}{|c|c|c|}
\hline Selenoprotein & Symbol & Function and Significance \\
\hline Glutathione peroxidase 1 & GPX1 & $\begin{array}{l}\text { Reduces cellular } \mathrm{H}_{2} \mathrm{O}_{2} \text {. Overexpression of GPX1 increases } \\
\text { risk of diabetes. }\end{array}$ \\
\hline Glutathione peroxidase 2 & GPX2 & $\begin{array}{l}\text { Reduces peroxide in gut. GPX1/GPX2 double-knockout } \\
\text { mice develop intestinal cancer; one allele of GPX2 added } \\
\text { back confers protection. }\end{array}$ \\
\hline Glutathione peroxidase 3 & GPX3 & $\begin{array}{l}\text { Reduces peroxide in blood. Important for cardiovascular } \\
\text { protection, perhaps through modulation of nitric oxide } \\
\text { levels; antioxidant in thyroid gland. }\end{array}$ \\
\hline Glutathione peroxidase 4 & GPX4 & $\begin{array}{l}\text { Reduces phospholipid peroxide. Genetic deletion is } \\
\text { embryonic lethal; GPX4 acts as crucial antioxidant, and } \\
\text { sensor of oxidative stress and pro-apoptotic signals; } \\
\text { required for spermatozoa function. }\end{array}$ \\
\hline Glutathione peroxidase 6 & GPX6 & Importance unknown. \\
\hline
\end{tabular}


Table 1. Cont.

\begin{tabular}{|c|c|c|}
\hline Selenoprotein & Symbol & Function and Significance \\
\hline Iodothyronine deiodinase 1 & DIO1 & Important for systemic active thyroid hormone levels. \\
\hline Iodothyronine deiodinase 2 & DIO2 & Important for local active thyroid hormone levels. \\
\hline Iodothyronine deiodinase 3 & $\mathrm{DIO} 3$ & Inactivates thyroid hormone. \\
\hline Thioredoxin reductase 1 & TXNRD1 & $\begin{array}{l}\text { Reduction of cytosolic thioredoxin. Genetic deletion is } \\
\text { embryonic lethal. }\end{array}$ \\
\hline Thioredoxin reductase 2 & TXNRD2 & $\begin{array}{l}\text { Reduction of mitochondrial thioredoxin. Genetic deletion } \\
\text { is embryonic lethal. }\end{array}$ \\
\hline Thioredoxin-glutathione reductase & TXNRD3 & Reduction of thioredoxin, testes-specific expression. \\
\hline Selenoprotein $\mathrm{H}$ & SELENOH & $\begin{array}{l}\text { Involved in transcription. Essential for cell survival and } \\
\text { antioxidant defense in Drosophila. }\end{array}$ \\
\hline Selenoprotein I & SELENOI & Possibly involved in phospholipid biosynthesis. \\
\hline Selenoprotein $\mathrm{K}$ & SELENOK & $\begin{array}{l}\text { Involved in calcium flux in immune cells and endoplasmic } \\
\text { reticulum (ER)-associated degradation. }\end{array}$ \\
\hline Selenoprotein M & SELENOM & $\begin{array}{l}\text { Thiol-disulfide oxidoreductase localized in the ER. } \\
\text { Possibly involved in protein folding. }\end{array}$ \\
\hline Selenoprotein F & SELENOF & $\begin{array}{l}\text { Thiol-disulfide oxidoreductase localized in the ER. } \\
\text { Possibly involved in protein folding. }\end{array}$ \\
\hline Selenoprotein $\mathrm{N}$ & SELENON & $\begin{array}{l}\text { Potential role in early muscle development. Mutations } \\
\text { lead to multiminicore disease and other myopathies. }\end{array}$ \\
\hline Selenoprotein $\mathrm{O}$ & SELENOO & $\begin{array}{l}\text { Potential redox function, but importance } \\
\text { remains unknown. }\end{array}$ \\
\hline Selenoprotein P & SELENOP & $\begin{array}{l}\text { Se transport to tissues particularly brain and testis. It also } \\
\text { functions as intracellular antioxidant in phagocytes. } \\
\text { Knockout leads to neurological problems and male sterility. }\end{array}$ \\
\hline Methionine-R-sulfoxide reductase 1 & MSRB1 & $\begin{array}{l}\text { Functions as a methionine sulfoxide reductase and MSRB1 } \\
\text { knockouts show mild damage to oxidative insult. }\end{array}$ \\
\hline Selenoprotein S & SELENOS & $\begin{array}{l}\text { Transmembrane protein found in plasma membrane and } \\
\text { ER. Reduces ER stress. }\end{array}$ \\
\hline Selenoprotein $\mathrm{T}$ & SELENOT & ER protein involved in calcium mobilization. \\
\hline Selenoprotein V & SELENOV & $\begin{array}{l}\text { Testes-specific expression, potential role in } \\
\text { male reproduction. }\end{array}$ \\
\hline Selenoprotein $\mathrm{W}$ & SELENOW & $\begin{array}{l}\text { Potential antioxidant role, perhaps important in } \\
\text { muscle growth. }\end{array}$ \\
\hline Selenophosphate synthetase 2 & SEPHS2 & Involved in the synthesis of all selenoproteins. \\
\hline
\end{tabular}

\subsection{Synthesis and Co-Translational Incorporation of Selenocysteine in Humans}

The cycle of selenocysteine synthesis and incorporation in humans begins with the attachment of L-serine to non-cognate tRNA ${ }^{\text {Sec }}$ by seryl-tRNA synthetase, an error that is not edited. This seryl group gets phosphorylated by O-phosphoseryl-tRNA ${ }^{\text {Sec }}$ kinase (PSTK) resulting in phosphoseryl (Sep)-tRNA ${ }^{\text {Sec }}$ intermediate. Finally, this Sep-tRNA ${ }^{\text {Sec }}$ is converted into selenocysteinyl (Sec)-tRNA ${ }^{\text {Sec }}$ through O-phosphoseryl-tRNA ${ }^{\text {Sec }}$ :selenocysteinyl-tRNA ${ }^{\text {Sec }}$ synthase (SepSecS) in the presence of selenophosphate and pyridoxal phosphate. Selenophosphate is the main Se donor in humans synthesized from adenosine triphosphate (ATP) and selenide, the products of selenocysteine degradation, by selenophosphate synthetase (SPS2). A specialized elongation factor (EFsec) then delivers Sec-tRNA ${ }^{\text {Sec }}$ to the ribosome. SElenoCysteine Insertion Sequence (SECIS), located in the 3'-UTR, helps localize EFsec and Sec-tRNA ${ }^{\text {Sec }}$ near the translation site and forms a stem loop structure which is necessary for decoding of selenocysteine UGA codon and its insertion into the nascent protein [14-17]. The cycle of selenocysteine synthesis and incorporation into selenoproteins in humans is summarized in Figure 1. 


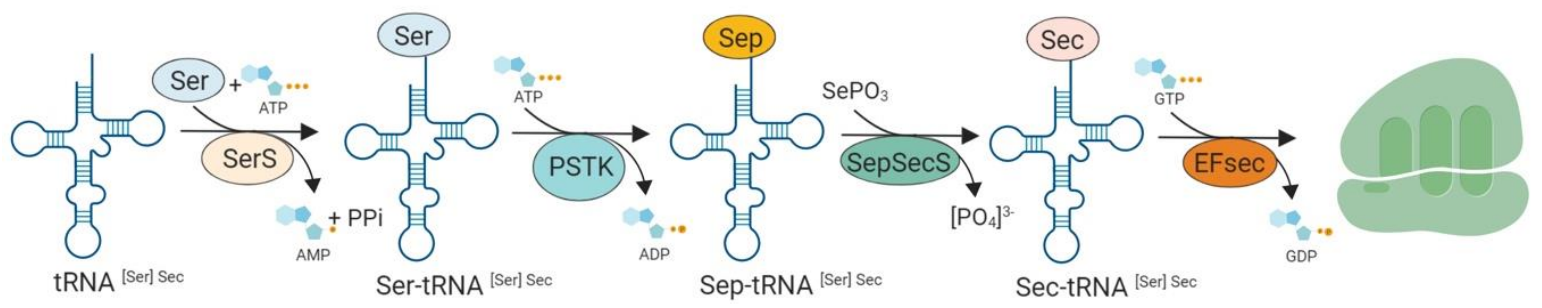

Figure 1. Synthesis and co-translational incorporation of selenocysteine into selenoproteins in humans.

\section{Selenium in Health and Disease: The Importance of a Balanced Intake}

Se depending on its status has been reported to play crucial roles in normal physiology or contribute the pathophysiology of various diseases. Se has antioxidant and anti-inflammatory actions and therefore various studies have assessed the impact of Se status on conditions characterized by inflammation and oxidative stress including, neurodegenerative diseases, diabetes, cancer, and cardiovascular disorders [18].

\subsection{Pregnancy}

During pregnancy, the demand for multiple nutrients increase owing to many physiological changes, resulting in deficiencies of many vitamins and minerals $[9,19]$. Those deficiencies might sometimes lead to complications to the fetus or to the mother. Se levels were found to be significantly reduced during pregnancy $[9,19]$. During the first trimester, GPx activity was found to be reduced significantly and this low level was maintained throughout the second and third trimesters with a slight increase during delivery [20]. Subsequently, in the second and third trimesters, Se levels were noted to be significantly reduced with further reduction during delivery [20]. Due to this increased demand, the RDA for Se during pregnancy was increased from $55 \mu \mathrm{g} /$ day to $60 \mu \mathrm{g} /$ day $[19,21]$. Se deficiencies in pregnant women might have adverse effects on the developing fetus, particularly the nervous system. A case-control study of pregnant women found a positive correlation between low Se levels and the occurrence of neural tube defects [22]. However, it is important to note that defects in the nervous system development are affected by multiple other factors and not solely by Se deficiencies. Se deficiencies during pregnancy were also found to cause oxidative stress partly resulting in miscarriages, pre-term deliveries, intrauterine growth retardations, preeclampsia, thyroid dysfunctions, gestational diabetes, and cholestasis $[9,23]$. Therefore, it is important to maintain optimal Se levels during pregnancy by increasing Se intake to meet the increased demand.

\subsection{Diabetes Mellitus}

The relationship between Se and diabetes was investigated in multiple studies with contradicting results [18]. Those studies were conducted initially following the assumption that Se is likely to exert protective effects against diabetes due to its antioxidant actions. In support of this assumption, Se was found to delay the onset and progression of diabetes. Se was also found to act as an insulin mimetic when in the form of selenite. Moreover, several in vitro and in vivo studies have suggested that Se plays an important role in the regulation of glucose homeostasis [18,24]. Human studies have also investigated the impact of Se on diabetes yet with conflicting conclusions. Both low and high levels of Se have been shown to be associated with a risk of diabetes [2]. The role of Se in diabetes was assessed in few randomized control trials (RCT). The first large RCT was the Nutritional Prevention of Cancer (NPC) trial which aimed at assessing the effect of $200 \mu \mathrm{g}$ of daily Se supplementation on reducing the risk of skin cancer compared to placebo [25]. A secondary analysis of the data after a follow-up of 7 years suggested a statistically significant increase in the incidence of type 2 diabetes among those who received Se supplementation compared to placebo [26]. In contrast, the Se and Vitamin E Cancer Prevention Trial (SELECT) found no statistically significant increase in the incidence of type 2 diabetes after Se supplementation [27]. The third trial is the Se and Celecoxib (Sel/Cel) Trial. 
The intervention was a randomized, placebo controlled trial of Se ( $200 \mu \mathrm{g} /$ day) and cyclooxygenase 2 selective inhibitor, celecoxib (400 mg, once per day), alone or in combination, for the prevention of colorectal adenoma in men and women. After exclusion of participants who had type 2 diabetes prior to the trial, 1640 participants were assessed for the presence of type 2 diabetes during the follow-up period. Authors found that 31 participants randomized to Se and 25 randomly assigned placebo were diagnosed with type 2 diabetes; however, despite a higher number of cases in the Se arm, the difference was not statistically significant. Interestingly, the study showed a statistically significant increase in the risk of type 2 diabetes in elderly individuals, which suggests that with old age supplementation with Se may increase the risk of type 2 diabetes [28]. These findings mirror the controversy on whether higher Se concentrations could increase the risk of type 2 diabetes or not.

Observational studies have also shown a non-linear association between Se and type 2 diabetes. A recent, comprehensive meta-analysis that was conducted in 2019 among 20 observational studies concluded that high Se levels are significantly associated with type 2 diabetes (pooled odds ratios, 1.88; $95 \%$ confidence interval, 1.44 to 2.45 ). However, significant heterogeneity was observed within different studies and the analysis of the funnel plot revealed significant publication bias. Subgroup analysis was also conducted according to the method of Se measurement in each study. Significant association was shown among studies that used blood, diet, and urine as specimens for Se level detection but not in studies that used nails as a sample for Se measurement. Sensitivity analysis was conducted in addition to the trim and fill analysis to account for the heterogeneity and the publication bias, yet the results were consistent upon all adjustments [18]. Another non-linear dose-response analysis confirmed that both levels below and above the physiological range are potential risk factors for diabetes which is consistent with other review articles that suggested a U-shaped relationship between Se and diabetes. Positive associations were detected among patients with low Se levels $(<100 \mu \mathrm{g} / \mathrm{l})$ and patients with high Se levels (>130 $\mu \mathrm{g} / \mathrm{l})$ [29].

\subsection{Cardiovascular Disease (CVD)}

Se as an antioxidant was assumed to play an essential role in protecting against atherosclerotic events and CVD [30]. Se deficiency was directly linked to Keshan disease, an endemic cardiomyopathy that is found in regions where Se intake is very low [31]. Multiple studies were carried out to assess the impact of Se on CVD risk. Both low and high levels of Se were found to adversely affect heart function [2]. In Eastern USA, a post hoc analysis of the NPC trial was conducted with a follow-up of 7.6 years to study the effect of Se supplementation on the prevention of CVD. The incidence of myocardial infarction, total cerebrovascular accidents and CVD were assessed, and the results revealed that there is no overall benefit of supplementing $200 \mu \mathrm{g} /$ day of Se to prevent CVD [26]. The SELECT trial did not also find any significant effect of Se on overall cardiovascular events [27]. A meta-analysis of RCTs showed that oral Se did not have an overall effect on cardiovascular events regardless of Se formulation or dose [32]. Observational studies have shown conflicting conclusions. A meta-analysis of observational studies concluded a nonlinear, U-shaped relationship, between Se levels and CVD risk. The suggested range of Se concentrations that results in significant beneficial effects against CVD is from 55 to $145 \mu \mathrm{g} / 1$ [32].

\subsection{Cancer}

The role of Se in cancer prevention was extensively studied in various cancer types. Se exerts its action through the antioxidant activity of selenoproteins in addition to several other mechanisms [33]. However, some laboratory studies suggested that Se can promote malignant cell transformation and progression [34]. Therefore, whether Se promotes or prevents cancer is not fully clear. Various RCTs investigated Se supplementation for cancer prevention. The first RCT is the NPC trial that aimed at assessing the influence of Se on the development of non-melanoma skin cancer. The NPC trial concluded that Se does not exert a chemoprotective effect against the recurrence of non-melanoma skin cancer, yet it significantly reduced the risk for all cancers, and for esophageal, prostate, colorectal, 
and lung cancers [25]. Another smaller trial among patients who received organ transplants found an unexpected increase in the incidence of non-melanoma skin cancer as a secondary outcome in Se-supplemented group [35]. The SELECT trial was a pivotal study that was carried out in male general population without high risk of prostate cancer to assess the incidence of prostate cancer among Se-supplemented participants compared to placebo. The study found no significant difference in prostate cancer incidence between Se-supplemented and placebo groups. It also detected no difference in overall cancer risk or any other cancer types [27]. Moreover, three recent RCTs evaluated Se impact on participants with high risk for prostate cancer and all showed no beneficial effect of Se on the incidence of cancer [36-38]. Additionally, a trial among women with high risk of breast cancer due to mutations to breast cancer type 1 (BRCA1) susceptibility gene showed increased risk of all cancers and primary breast cancer in Se-supplemented arm compared to placebo [39]. Observational studies have also assessed Se effect on cancer risk with strongly conflicting results. A recent meta-analysis of observational cohort studies showed an overall lower risk of cancer among participants with the highest baseline exposure levels, yet the included studies are subject to a substantial risk of bias [40].

\section{Regional Variability of Se Status: A Focus on the Situation in the Middle Eastern and North Africa (MENA) Region}

The status of Se across the MENA region is widely variable with some countries deficient, some over sufficient and some sufficient in addition to several countries with unknown Se status. This variability was apparent even between provinces from the same country. These tremendous variations may be linked to the varying concentration of Se in the soil were food consumed is gown. We summarized in this review the available evidence on Se status and intake among countries of the MENA region. It is important to note that most of the studies that assessed Se concentrations in biological samples were case-control studies with small sample sizes that cannot be generalized to the whole population. Few studies addressed Se status in a small number of countries with total paucity of information in many other countries of the MENA region. Available evidence on Se status among countries of the MENA region are summarized in Figure 2.

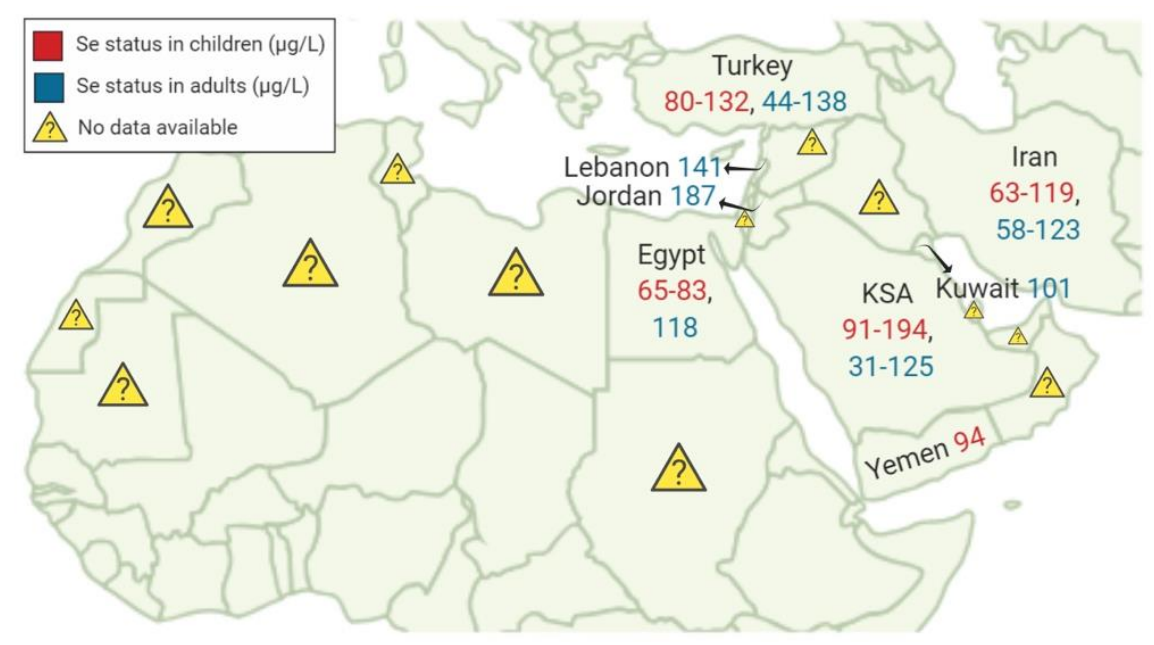

Figure 2. Available data on Se status in children and adults among countries of the MENA region.

\subsection{Turkey}

A study that analyzed Se concentrations in colostrum, transitional and mature breast milk among healthy lactating women concluded that Se content is below the international reference range set at $18.5 \mu \mathrm{g} / \mathrm{l}$ among all different samples throughout the lactation period [41]. Moreover, analysis was extended to dairy milk products in Turkey collected from different cities and its findings revealed that goat milk had the highest content followed by sheep milk and finally cow milk had the lowest Se content [41]. A more recent study included all dairy products in the analysis and 
found that concentrations varied based on the type of food with butter and cheese having higher concentrations; however, other products such as ice cream, milk, and yogurt had almost no Se content [42]. The estimated daily intake of Se among children was reported as 30-40 $\mu \mathrm{g} / \mathrm{day}$ [43]. However, with regards to Se concentrations in blood, multiple case-control studies were conducted among different healthy and patient populations including infants, children, adults, pregnant women, and postmenopausal women. Other studies also used samples from erythrocytes and semen to assess Se concentrations [44,45]. Overall, values were widely variable ranging from 50-138 $\mu \mathrm{g} / \mathrm{l}$ in healthy populations [43-55].

\subsection{Jordan}

A survey of groundwater was conducted to assess the levels of Se in multiple aquifers in Amman Zarqa Basin. Se levels were various among different aquifers ranging from 0.09 to $742 \mu \mathrm{g} / \mathrm{l}$ with an average of $24 \mu \mathrm{g} / \mathrm{l}$, which exceeds WHO recommended threshold for drinking water [56]. A later case-control study of colorectal cancer patients assessed the dietary intake of Se which was found to be $59.26 \pm 8.91 \mu \mathrm{g} / \mathrm{day}$ for controls. This value is higher than the RDA (55-70 $\mu \mathrm{g} / \mathrm{day})$ [57]. On the other hand, Se concentrations were analyzed in two studies using blood and hair samples [58,59]. Blood concentrations in non-smokers were found to be around $187 \mu \mathrm{g} / \mathrm{l}$ which is relatively high [58].

\subsection{Iran}

Multiple studies were conducted in Iran among various populations, children, adults, and elderly [60-62]. Se intake was found to be adequate in children and adults [60,61], whereas in postmenopausal women, Se intake was significantly lower than the RDA (55 $\mu \mathrm{g} /$ day) [62]. Se levels in rice samples from Iran were assessed and they were found to be relatively high [63]. Se status in Iran was assessed in various studies in healthy and patient populations. Blood concentrations ranged from $58-123 \mu \mathrm{g} / \mathrm{l}$ in children, adults and pregnant women [64-77].

\subsection{Kingdom of Saudi Arabia (KSA)}

A study was conducted to assess the content of Se in wheat grains grown in KSA. This study reported highly variable concentrations ranging from 8 to $293 \mu \mathrm{g} / \mathrm{kg}$ [78]. Other recent studies that quantified the intake of Se estimated the intake to be 75-121.65 $\mu \mathrm{g} /$ day and $93 \mu \mathrm{g} /$ day in the regions of Jeddah and Riyadh, respectively [79,80]. Moreover, surveys of infant milk formulas, breast milk and cow's milk were conducted to determine Se intake in infant/children populations. The findings of those surveys showed that infant milk formulas contained adequate amounts of Se whereas some breast-fed infants might have lower than recommended Se intakes [81,82]. On the other hand, Se status was assessed in multiple case-control studies in KSA. Those studies were done using various samples; serum, urine, toenails, whole blood, umbilical cord blood, and placental tissue [5,80,83-91]. Blood concentrations varied widely from as low as $32 \mu \mathrm{g} / \mathrm{l}$ to $195 \mu \mathrm{g} / \mathrm{l}[5,80,85-88,90,91]$.

\subsection{Egypt}

Se intake among healthy children in Egypt was found to be $8.3 \pm 2.3 \mathrm{mg} / \mathrm{day}$ [92]. Case-control studies in Egypt were mainly done on children, and reported Se concentrations ranging from 65-83 $\mu \mathrm{g} / 1$ [93-95]. Studies have also assessed Se concentrations in neonates and their mothers and the concentrations were found to be $86 \mu \mathrm{g} / \mathrm{l}$ and $118 \mu \mathrm{g} / \mathrm{l}$, respectively [96].

\subsection{Qatar}

In Qatar, no direct studies were conducted to assess the intake of Se among Qatari population. However, according to Qatar General Electricity \& Water Corporation (Kahramaa) drinking water quality requirements report, Se is not expected to be present in Qatar's water system [97]. This indicates that the Qatari population is not expected to have any Se intake from drinking water sources. 
Additionally, a market basket survey of Se in rice imports in Qatar, the primary staple dish, concluded that for Qatari citizens, rice compensates for more than 100\% of RNI Se (30 $\mu \mathrm{g} / \mathrm{day}$ ) regardless of the gender or the type of rice consumed. However, for non-Qatari expatriates (over $80 \%$ of the population), with a much lower rice consumption, the percentages were variable according to gender and type of rice consumed, yet they were all below $100 \%$ of RNI Se [98]. Further analysis included rice-based infant cereals in Qatar which was found to provide around 63\% of RNI Se based on the recommended daily serving [98]. This can conclude that rice consumption in Qatar is a significant contributor to the daily intake of Se. However, Se status in Qatar was not assessed in any of the few studies available.

\section{Conclusions}

Se plays a very important role in health and hence Se status and intake are very important to be known for a specific population as the levels of Se are highly variable among different populations and regions. Studies conducted in the MENA region to assess Se status and intake are very limited and most of those available were designed as case-control protocols with small sample sizes. For those countries with data available such as Iran, Turkey, and KSA, more powered, rigorous, and well-designed studies should be conducted to assess Se status among different populations in that specific country or regions that share more or less similar lifestyle and climate such as the six countries of the Gulf Cooperation Council (GCC). Se intake should also be assessed using food surveys and through surveying Se content in staple food (e.g., rice) especially that most of food products consumed in a large number of countries of the MENA region are imported from various parts of the world which may have variable Se content in the soil. Moreover, for many countries within the MENA region, including Qatar and most North-African countries, data about Se status is totally absent. This warrants the need for rigorous and well-constructed studies to determine Se intake and status among the general population and specific populations, such as children and pregnant women, in those countries. Furthermore, studying the relationship between Se status and the incidence of chronic diseases, such as diabetes and CVD in the MENA region would help in devising novel preventive approaches for these disorders particularly prevalent in many countries of this region.

Author Contributions: A.A. conceptualized the idea. A.A. and S.A.Z.I. wrote the manuscript. A.K. contributed to selected sections and edited the manuscript. A.A. coordinated the writing up and the submission process. All authors approved the final version for submission.

Funding: Our work is supported by award NPRP-8-1750-3-360 from Qatar National Research Fund (a member of Qatar Foundation) to A.A. The statements made herein are solely the responsibility of the authors.

Acknowledgments: The figures in this article were created with BioRender.

Conflicts of Interest: The authors declare no conflict of interest.

\section{References}

1. Weeks, M.E. The discovery of the elements. VI. Tellurium and selenium. J. Chem. Educ. 1932, 9, 474. [CrossRef]

2. Zachariah, M. High Selenium Induces Endothelial Dysfunction Via Endoplasmic Reticulum Stress. Ph.D. Thesis, University of Surrey, Guildford, UK, 2017.

3. Stoffaneller, R.; Morse, L.N. A Review of Dietary Selenium Intake and Selenium Status in Europe and the Middle East. Nutrients 2015, 7, 1494-1537. [CrossRef] [PubMed]

4. Prabhu, K.S.; Lei, X.G. Selenium. Adv. Nutr. 2016, 7, 415-417. [CrossRef] [PubMed]

5. Al-Daghri, N.M.; Al-Attas, O.; Yakout, S.; Aljohani, N.; Al-Fawaz, H.; Alokail, M.S. Dietary products consumption in relation to serum 25-hydroxyvitamin $\mathrm{D}$ and selenium level in Saudi children and adults. Int. J. Clin. Exp. Med. 2015, 8, 1305-1314. [PubMed]

6. Qazi, I.H.; Angel, C.; Yang, H.; Pan, B.; Zoidis, E.; Zeng, C.J.; Han, H.; Zhou, G.B. Selenium, Selenoproteins, and Female Reproduction: A Review. Molecules 2018, 23, 3053. [CrossRef] [PubMed]

7. Bleys, J.; Navas-Acien, A.; Guallar, E. Serum selenium levels and all-cause, cancer, and cardiovascular mortality among US adults. Arch. Intern. Med. 2008, 168, 404-410. [CrossRef] 
8. Rocourt, C.R.; Cheng, W.H. Selenium supranutrition: Are the potential benefits of chemoprevention outweighed by the promotion of diabetes and insulin resistance? Nutrients 2013, 5, 1349-1365. [CrossRef]

9. Pieczyńska, J.; Grajeta, H. The role of selenium in human conception and pregnancy. J. Trace Elem. Med. Biol. 2015, 29, 31-38. [CrossRef]

10. Combs, F., Jr. Biomarkers of selenium status. Nutrients 2015, 7, 2209-2236. [CrossRef]

11. Papp, L.V.; Lu, J.; Holmgren, A.; Khanna, K.K. From selenium to selenoproteins: Synthesis, identity, and their role in human health. Antioxid. Redox Signal. 2007, 9, 775-806. [CrossRef]

12. Rayman, M.P. The importance of selenium to human health. Lancet 2000, 356, 233-241. [CrossRef]

13. Rayman, M.P. Selenium and human health. Lancet 2012, 379, 1256-1268. [CrossRef]

14. Xu, X.-M.; Carlson, B.A.; Mix, H.; Zhang, Y.; Saira, K.; Glass, R.S.; Berry, M.J.; Gladyshev, V.N.; Hatfield, D.L. Biosynthesis of selenocysteine on its tRNA in eukaryotes. PLoS Biol. 2007, 5, e4. [CrossRef] [PubMed]

15. Turanov, A.A.; Xu, X.-M.; Carlson, B.A.; Yoo, M.-H.; Gladyshev, V.N.; Hatfield, D.L. Biosynthesis of selenocysteine, the 21st amino acid in the genetic code, and a novel pathway for cysteine biosynthesis. Adv. Nutr. 2011, 2, 122-128. [CrossRef] [PubMed]

16. Schmidt, R.L.; Simonović, M. Synthesis and decoding of selenocysteine and human health. Croat. Med. J. 2012, 53, 535-550. [CrossRef] [PubMed]

17. Labunskyy, V.M.; Hatfield, D.L.; Gladyshev, V.N. Selenoproteins: Molecular pathways and physiological roles. Physiol. Rev. 2014, 94, 739-777. [CrossRef]

18. Kim, J.; Chung, H.S.; Choi, M.-K.; Roh, Y.K.; Yoo, H.J.; Park, J.H.; Kim, D.S.; Yu, J.M.; Moon, S. Association between Serum Selenium Level and the Presence of Diabetes Mellitus: A Meta-Analysis of Observational Studies. Diabetes Metab. J. 2019, 43, e1. [CrossRef] [PubMed]

19. Lewicka, I.; Kocyłowski, R.; Grzesiak, M.; Gaj, Z.; Oszukowski, P.; Suliburska, J. Selected trace elements concentrations in pregnancy and their possible role-Literature review. Ginekol. Pol. 2017, 88, 509-514. [CrossRef] [PubMed]

20. Mihailovic, M.; Cvetkovic, M.; Ljubic, A.; Kosanovic, M.; Nedeljkovic, S.; Jovanovic, I.; Pesut, O. Selenium and malondialdehyde content and glutathione peroxidase activity in maternal and umbilical cord blood and amniotic fluid. Biol. Trace Elem. Res. 2000, 73, 47-54. [CrossRef]

21. Mistry, H.D.; Broughton Pipkin, F.; Redman, C.W.; Poston, L. Selenium in reproductive health. Am. J. Obstet. Gynecol. 2012, 206, 21-30. [CrossRef] [PubMed]

22. Cengiz, B.; Soylemez, F.; Ozturk, E.; Cavdar, A.O. Serum zinc, selenium, copper, and lead levels in women with second-trimester induced abortion resulting from neural tube defects: A preliminary study. Biol. Trace Elem. Res. 2004, 97, 225-235. [CrossRef]

23. Zachara, B.A. Chapter Five-Selenium in Complicated Pregnancy. A Review. Adv. Clin. Chem. 2018, 86, 157-178.

24. Zhou, J.; Huang, K.; Lei, X.G. Selenium and diabetes-evidence from animal studies. Free Radic. Biol. Med. 2013, 65, 1548-1556. [CrossRef] [PubMed]

25. Clark, L.C.; Combs, G.F.; Turnbull, B.W.; Slate, E.H.; Chalker, D.K.; Chow, J.; Davis, L.S.; Glover, R.A.; Graham, G.F.; Gross, E.G.; et al. Effects of selenium supplementation for cancer prevention in patients with carcinoma of the skin. A randomized controlled trial. Nutritional Prevention of Cancer Study Group. JAMA 1996, 276, 1957-1963. [CrossRef] [PubMed]

26. Stranges, S.; Marshall, J.R.; Natarajan, R.; Donahue, R.P.; Trevisan, M.; Combs, G.F.; Cappuccio, F.P.; Ceriello, A.; Reid, M.E. Effects of long-term selenium supplementation on the incidence of type 2 diabetes: A randomized trial. Ann. Intern. Med. 2007, 147, 217-223. [CrossRef] [PubMed]

27. Lippman, S.M.; Klein, E.A.; Goodman, P.J.; Lucia, M.S.; Thompson, I.M.; Ford, L.G.; Parnes, H.L.; Minasian, L.M.; Gaziano, J.M.; Hartline, J.A.; et al. Effect of selenium and vitamin E on risk of prostate cancer and other cancers: The Selenium and Vitamin E Cancer Prevention Trial (SELECT). JAMA 2009, 301, 39-51. [CrossRef] [PubMed]

28. Thompson, P.A.; Ashbeck, E.L.; Roe, D.J.; Fales, L.; Buckmeier, J.; Wang, F.; Bhattacharyya, A.; Hsu, C.H.; Chow, H.H.; Ahnen, D.J.; et al. Selenium Supplementation for Prevention of Colorectal Adenomas and Risk of Associated Type 2 Diabetes. J. Natl. Cancer Inst. 2016, 108. [CrossRef]

29. Wang, X.-L.; Yang, T.-B.; Wei, J.; Lei, G.-H.; Zeng, C. Association between serum selenium level and type 2 diabetes mellitus: A non-linear dose-response meta-analysis of observational studies. Nutr. J. 2016, 15, 48. [CrossRef] 
30. Benstoem, C.; Goetzenich, A.; Kraemer, S.; Borosch, S.; Manzanares, W.; Hardy, G.; Stoppe, C. Selenium and its supplementation in cardiovascular disease-What do we know? Nutrients 2015, 7, 3094-3118. [CrossRef]

31. Thomson, C.D. Assessment of requirements for selenium and adequacy of selenium status: A review. Eur. J. Clin. Nutr. 2004, 58, 391-402. [CrossRef]

32. Zhang, X.; Liu, C.; Guo, J.; Song, Y. Selenium status and cardiovascular diseases: Meta-analysis of prospective observational studies and randomized controlled trials. Eur. J. Clin. Nutr. 2016, 70, 162-169. [CrossRef] [PubMed]

33. Tan, H.W.; Mo, H.-Y.; Lau, A.T.Y.; Xu, Y.-M. Selenium Species: Current Status and Potentials in Cancer Prevention and Therapy. Int. J. Mol. Sci. 2018, 20, 75. [CrossRef] [PubMed]

34. Hatfield, D.L.; Tsuji, P.A.; Carlson, B.A.; Gladyshev, V.N. Selenium and selenocysteine: Roles in cancer, health, and development. Trends Biochem. Sci. 2014, 39, 112-120. [CrossRef] [PubMed]

35. Dreno, B.; Euvrard, S.; Frances, C.; Moyse, D.; Nandeuil, A. Effect of selenium intake on the prevention of cutaneous epithelial lesions in organ transplant recipients. Eur. J. Dermatol. EJD 2007, 17, 140-145. [CrossRef] [PubMed]

36. Karp, D.D.; Lee, S.J.; Keller, S.M.; Wright, G.S.; Aisner, S.; Belinsky, S.A.; Johnson, D.H.; Johnston, M.R.; Goodman, G.; Clamon, G.; et al. Randomized, double-blind, placebo-controlled, phase III chemoprevention trial of selenium supplementation in patients with resected stage I non-small-cell lung cancer: ECOG 5597. J. Clin. Oncol. 2013, 31, 4179-4187. [CrossRef] [PubMed]

37. Marshall, J.R.; Tangen, C.M.; Sakr, W.A.; Wood, D.P.; Berry, D.L.; Klein, E.A.; Lippman, S.M.; Parnes, H.L.; Alberts, D.S.; Jarrard, D.F.; et al. Phase III trial of selenium to prevent prostate cancer in men with high-grade prostatic intraepithelial neoplasia: SWOG S9917. Cancer Prev. Res. 2011, 4, 1761-1769. [CrossRef]

38. Algotar, A.M.; Stratton, M.S.; Ahmann, F.R.; Ranger-Moore, J.; Nagle, R.B.; Thompson, P.A.; Slate, E.; Hsu, C.H.; Dalkin, B.L.; Sindhwani, P.; et al. Phase 3 clinical trial investigating the effect of selenium supplementation in men at high-risk for prostate cancer. Prostate 2013, 73, 328-335. [CrossRef] [PubMed]

39. Lubinski, J.; Jaworska, K.; Durda, K.; Jakubowska, A.; Huzarski, T.; Byrski, T.; Stawicka, M.; Gronwald, J.; Górski, B.; Wasowicz, W.; et al. Selenium and the risk of cancer in BRCA1 carriers. Hered. Cancer Clin. Pract. 2011, 9, A5. [CrossRef]

40. Vinceti, M.; Filippini, T.; Del Giovane, C.; Dennert, G.; Zwahlen, M.; Brinkman, M.; Zeegers, M.P.; Horneber, M.; D'Amico, R.; Crespi, C.M. Selenium for preventing cancer. Cochrane Database Syst. Rev. 2018, 1, CD005195. [CrossRef]

41. Yanardag, R.; Orak, H. Selenium content of milk and milk products of Turkey. II. Biol. Trace Elem. Res. 1999, 68, 79-95. [CrossRef]

42. Ayar, A.; Sert, D.; Akin, N. The trace metal levels in milk and dairy products consumed in middle Anatolia-Turkey. Environ. Monit. Assess. 2009, 152, 1-12. [CrossRef] [PubMed]

43. Hincal, F. Trace elements in growth: Iodine and selenium status of Turkish children. J. Trace Elem. Med. Biol. 2007, 21, 40-43. [CrossRef]

44. Erkekoglu, P.; Asci, A.; Ceyhan, M.; Kizilgun, M.; Schweizer, U.; Atas, C.; Kara, A.; Kocer Giray, B. Selenium levels, selenoenzyme activities and oxidant/antioxidant parameters in H1N1-infected children. Turk. J. Pediatr. 2013, 55, 271-282. [PubMed]

45. Eroglu, M.; Sahin, S.; Durukan, B.; Ozakpinar, O.B.; Erdinc, N.; Turkgeldi, L.; Sofuoglu, K.; Karateke, A. Blood serum and seminal plasma selenium, total antioxidant capacity and coenzyme q10 levels in relation to semen parameters in men with idiopathic infertility. Biol. Trace Elem. Res. 2014, 159, 46-51. [CrossRef] [PubMed]

46. Ozdemir, H.S.; Karadas, F.; Pappas, A.C.; Cassey, P.; Oto, G.; Tuncer, O. The selenium levels of mothers and their neonates using hair, breast milk, meconium, and maternal and umbilical cord blood in Van Basin. Biol. Trace Elem. Res. 2008, 122, 206-215. [CrossRef]

47. Hincal, F.; Basaran, N.; Yetgin, S.; Gokmen, O. Selenium status in Turkey. II. Serum selenium concentration in healthy residents of different ages in Ankara. J. Trace Elem. Electrol. Health Dis. 1994, 8, 9-12.

48. Kilinc, M.; Guven, M.A.; Ezer, M.; Ertas, I.E.; Coskun, A. Evaluation of serum selenium levels in Turkish women with gestational diabetes mellitus, glucose intolerants, and normal controls. Biol. Trace Elem. Res. 2008, 123, 35-40. [CrossRef] [PubMed]

49. Seven, M.; Basaran, S.Y.; Cengiz, M.; Unal, S.; Yuksel, A. Deficiency of selenium and zinc as a causative factor for idiopathic intractable epilepsy. Epilepsy Res. 2013, 104, 35-39. [CrossRef] 
50. Bay, A.; Dogan, M.; Bulan, K.; Kaba, S.; Demir, N.; Oner, A.F. A study on the effects of pica and iron-deficiency anemia on oxidative stress, antioxidant capacity and trace elements. Hum. Exp. Toxicol. 2013, 32, 895-903. [CrossRef]

51. Coskun, A.; Arikan, T.; Kilinc, M.; Arikan, D.C.; Ekerbicer, H.C. Plasma selenium levels in Turkish women with polycystic ovary syndrome. Eur. J. Obstet. Gynecol. Reprod. Biol. 2013, 168, 183-186. [CrossRef]

52. Arikan, D.C.; Coskun, A.; Ozer, A.; Kilinc, M.; Atalay, F.; Arikan, T. Plasma selenium, zinc, copper and lipid levels in postmenopausal Turkish women and their relation with osteoporosis. Biol. Trace Elem. Res. 2011, 144, 407-417. [CrossRef] [PubMed]

53. Sakiz, D.; Kaya, A.; Kulaksizoglu, M. Serum Selenium Levels in Euthyroid Nodular Thyroid Diseases. Biol. Trace Elem. Res. 2016, 174, 21-26. [CrossRef] [PubMed]

54. Arikan, T.A. Plasma Selenium Levels in First Trimester Pregnant Women with Hyperthyroidism and the Relationship with Thyroid Hormone Status. Biol. Trace Elem. Res. 2015, 167, 194-199. [CrossRef] [PubMed]

55. Aydemir, B.; Akdemir, R.; Vatan, M.B.; Cinemre, F.B.; Cinemre, H.; Kiziler, A.R.; Bahtiyar, N.; Buyukokuroglu, M.E.; Gurol, G.; Ogut, S. The Circulating Levels of Selenium, Zinc, Midkine, Some Inflammatory Cytokines, and Angiogenic Factors in Mitral Chordae Tendineae Rupture. Biol. Trace Elem. Res. 2015, 167, 179-186. [CrossRef] [PubMed]

56. Kuisi, M.A.; Abdel-Fattah, A. Groundwater vulnerability to selenium in semi-arid environments: Amman Zarqa Basin, Jordan. Environ. Geochem. Health 2010, 32, 107-128. [CrossRef] [PubMed]

57. Arafa, M.A.; Waly, M.I.; Jriesat, S.; Al Khafajei, A.; Sallam, S. Dietary and lifestyle characteristics of colorectal cancer in Jordan: A case-control study. Asian Pac. J. Cancer Prev. 2011, 12, 1931-1936. [PubMed]

58. Massadeh, A.; Gharibeh, A.; Omari, K.; Al-Momani, I.; Alomary, A.; Tumah, H.; Hayajneh, W. Simultaneous determination of $\mathrm{Cd}, \mathrm{Pb}, \mathrm{Cu}, \mathrm{Zn}$, and $\mathrm{Se}$ in human blood of jordanian smokers by ICP-OES. Biol. Trace Elem. Res. 2010, 133, 1-11. [CrossRef]

59. Alqhazo, M.; Rashaid, A.B. The concentrations of bioelements in the hair samples of Jordanian children who stutter. Int. J. Pediatr. Otorhinolaryngol. 2018, 112, 158-162. [CrossRef]

60. Mirzaeian, S.; Ghiasvand, R.; Sadeghian, F.; Sheikhi, M.; Khosravi, Z.S.; Askari, G.; Shiranian, A.; Yadegarfar, G. Assessing the micronutrient and macronutrient intakes in female students and comparing them with the set standard values. J. Educ. Health Promot. 2013, 2, 1. [CrossRef]

61. Darvishi, L.; Ghiasvand, R.; Ashrafi, M.; Ashrafzadeh, E.; Askari, G.; Shiranian, A.; Hasanzadeh, A. Relationship between junk foods intake and weight in 6-7 years old children, Shahin Shahr and Meymeh, Iran. J. Educ. Health Promot. 2013, 2, 2. [CrossRef]

62. Mansour, A.; Ahadi, Z.; Qorbani, M.; Hosseini, S. Association between dietary intake and seasonal variations in postmenopausal women. J. Diabetes Metab. Disord. 2014, 13, 52. [CrossRef] [PubMed]

63. Rahimzadeh-Barzoki, H.; Joshaghani, H.; Beirami, S.; Mansurian, M.; Semnani, S.; Roshandel, G. Selenium levels in rice samples from high and low risk areas for esophageal cancer. Saudi Med. J. 2014, 35, 617-620. [PubMed]

64. Safaralizadeh, R.; Kardar, G.A.; Pourpak, Z.; Moin, M.; Zare, A.; Teimourian, S. Serum concentration of selenium in healthy individuals living in Tehran. Nutr. J. 2005, 4, 32. [CrossRef] [PubMed]

65. Safaralizadeh, R.; Sirjani, M.; Pourpak, Z.; Kardar, G.; Teimourian, S.; Shams, S.; Namdar, Z.; Kazemnejad, A.; Moin, M. Serum selenium concentration in healthy children living in Tehran. Biofactors 2007, 31, 127-131. [CrossRef] [PubMed]

66. Dabbaghmanesh, M.H.; Sadegholvaad, A.; Ejtehadi, F.; Omrani, G. Low serum selenium concentration as a possible factor for persistent goiter in Iranian school children. Biofactors 2007, 29, 77-82. [CrossRef] [PubMed]

67. Farzin, L.; Moassesi, M.E.; Sajadi, F.; Amiri, M.; Shams, H. Serum levels of antioxidants (Zn, Cu, Se) in healthy volunteers living in Tehran. Biol. Trace Elem. Res. 2009, 129, 36-45. [CrossRef] [PubMed]

68. Farzin, L.; Sajadi, F. Comparison of serum trace element levels in patients with or without pre-eclampsia. J. Res. Med. Sci. 2012, 17, 938-941. [PubMed]

69. Farzin, L.; Moassesi, M.E. A comparison of serum selenium, zinc and copper level in visceral and cutaneous leishmaniasis. J. Res. Med. Sci. 2014, 19, 355-357.

70. Parizadeh, S.M.; Moohebati, M.; Ghafoori, F.; Ghayour-Mobarhan, M.; Kazemi-Bajestani, S.M.; Tavallaie, S.; Azimi-Nezhad, M.; Ferns, G.A. Serum selenium and glutathione peroxidase concentrations in Iranian patients with angiography-defined coronary artery disease. Angiology 2009, 60, 186-191. [CrossRef] 
71. Rafraf, M.; Mahdavi, R.; Rashidi, M.R. Serum selenium levels in healthy women in Tabriz, Iran. Food Nutr. Bull. 2008, 29, 83-86. [CrossRef]

72. Tara, F.; Rayman, M.P.; Boskabadi, H.; Ghayour-Mobarhan, M.; Sahebkar, A.; Yazarlu, O.; Ouladan, S.; Tavallaie, S.; Azimi-Nezhad, M.; Shakeri, M.T.; et al. Selenium supplementation and premature (pre-labour) rupture of membranes: A randomised double-blind placebo-controlled trial. J. Obstet. Gynaecol. 2010, 30, 30-34. [CrossRef] [PubMed]

73. Mahyar, A.; Ayazi, P.; Fallahi, M.; Javadi, A. Correlation between serum selenium level and febrile seizures. Pediatric Neurol. 2010, 43, 331-334. [CrossRef] [PubMed]

74. Esalatmanesh, K.; Jamshidi, A.; Shahram, F.; Davatchi, F.; Masoud, S.A.; Soleimani, Z.; Salesi, M.; Ghaffarpasand, I. Study of the correlation of serum selenium level with Behcet's disease. Int. J. Rheum. Dis. 2011, 14, 375-378. [CrossRef] [PubMed]

75. Ghaemian, A.; Salehifar, E.; Shiraj, H.; Babaee, Z. A Comparison of Selenium Concentrations between Congestive Heart Failure Patients and Healthy Volunteers. J. Tehran Heart Cent. 2012, 7, 53-57. [PubMed]

76. Ghaemi, S.Z.; Forouhari, S.; Dabbaghmanesh, M.H.; Sayadi, M.; Bakhshayeshkaram, M.; Vaziri, F.; Tavana, Z. A prospective study of selenium concentration and risk of preeclampsia in pregnant Iranian women: A nested case-control study. Biol. Trace Elem. Res. 2013, 152, 174-179. [CrossRef] [PubMed]

77. Maleki, A.; Fard, M.K.; Zadeh, D.H.; Mamegani, M.A.; Abasaizadeh, S.; Mazloomzadeh, S. The relationship between plasma level of Se and preeclampsia. Hypertens. Pregnancy 2011, 30, 180-187. [CrossRef] [PubMed]

78. Al-Saleh, I.A.; Al-Jaloud, A.; Al-Doush, I.; El-Din, G. The distribution of selenium levels in Saudi dairy farms: A preliminary report from Al-Kharj. J. Environ. Pathol. Toxicol. Oncol. Off. Organ Int. Soc. Environ. Toxicol. Cancer 1999, 18, 37-46.

79. Al-Ahmary, K.M. Selenium content in selected foods from the Saudi Arabia market and estimation of the daily intake. Arab. J. Chem. 2009, 2, 95-99. [CrossRef]

80. Al-Othman, A.M.; Al-Othman, Z.A.; El-Desoky, G.E.; Aboul-Soud, M.A.; Habila, M.A.; Giesy, J.P. Daily intake of selenium and concentrations in blood of residents of Riyadh City, Saudi Arabia. Environ. Geochem. Health 2012, 34, 417-431. [CrossRef] [PubMed]

81. Al-Saleh, I.; Al-Doush, I. Selenium levels in infant milk formula. Biometals Int. J. Role Met. Ions Biol. Biochem. Med. 1997, 10, 299-302. [CrossRef]

82. Al-Saleh, I.; Al-Doush, I.; Faris, R. Selenium levels in breast milk and cow's milk: A preliminary report from Saudi Arabia. J. Environ. Pathol. Toxicol. Oncol. Off. Organ Int. Soc. Environ. Toxicol. Cancer 1997, 16, 41-46.

83. Al-Saleh, I.; El-Doush, I.; Billedo, G.; Mohamed Gel, D.; Yosef, G. Status of selenium, vitamin E, and vitamin A among Saudi adults: Potential links with common endemic diseases. J. Environ. Pathol. Toxicol. Oncol. Off. Organ Int. Soc. Environ. Toxicol. Cancer 2007, 26, 221-243. [CrossRef]

84. Al-Saleh, I.; Billedo, G. Determination of selenium concentration in serum and toenail as an indicator of selenium status. Bull. Environ. Contam. Toxicol. 2006, 77, 155-163. [CrossRef] [PubMed]

85. Al-Saleh, I.; Al-Doush, I.; Ibrahim, M.; Rabbah, A. Serum selenium levels in Saudi new-borns. Int. J. Environ. Health Res. 1998, 8, 269-275. [CrossRef]

86. Al-Saleh, I.; Billedo, G.; El-Doush, I.; El-Din Mohamed, G.; Yosef, G. Selenium and vitamins status in Saudi children. Clin. Chim. Acta Int. J. Clin. Chem. 2006, 368, 99-109. [CrossRef] [PubMed]

87. Al-Saleh, E.; Nandakumaran, M.; Al-Rashdan, I.; Al-Harmi, J.; Al-Shammari, M. Maternal-foetal status of copper, iron, molybdenum, selenium and zinc in obese gestational diabetic pregnancies. Acta Diabetol. 2007, 44, 106-113. [CrossRef] [PubMed]

88. Alissa, E.M.; Ahmed, W.H.; Al-ama, N.; Ferns, G.A. Selenium status and cardiovascular risk profile in healthy adult Saudi males. Molecules 2008, 14, 141-159. [CrossRef] [PubMed]

89. El-Yazigi, A.; Legayada, E. Urinary selenium in healthy and diabetic Saudi Arabians. Biol. Trace Elem. Res. 1996, 52, 55-63. [CrossRef] [PubMed]

90. Ghneim, H.K.; Alshebly, M.M. Biochemical Markers of Oxidative Stress in Saudi Women with Recurrent Miscarriage. J. Korean Med. Sci. 2016, 31, 98-105. [CrossRef]

91. El-Ansary, A.; Bjorklund, G.; Tinkov, A.A.; Skalny, A.V.; Al Dera, H. Relationship between selenium, lead, and mercury in red blood cells of Saudi autistic children. Metab. Brain Dis. 2017, 32, 1073-1080. [CrossRef]

92. Meguid, N.A.; Anwar, M.; Bjorklund, G.; Hashish, A.; Chirumbolo, S.; Hemimi, M.; Sultan, E. Dietary adequacy of Egyptian children with autism spectrum disorder compared to healthy developing children. Metab. Brain Dis. 2017, 32, 607-615. [CrossRef] [PubMed] 
93. Saad, K.; Farghaly, H.S.; Badry, R.; Othman, H.A. Selenium and antioxidant levels decreased in blood of children with breath-holding spells. J. Child Neurol. 2014, 29, 1339-1343. [CrossRef] [PubMed]

94. Sherief, L.M.; Abd El-Salam, S.M.; Kamal, N.M.; El safy, O.; Almalky, M.A.A.; Azab, S.F.; Morsy, H.M.; Gharieb, A.F. Nutritional Biomarkers in Children and Adolescents with Beta-Thalassemia-Major: An Egyptian Center Experience. BioMed Res. Int. 2014, 2014, 1-7. [CrossRef] [PubMed]

95. Azab, S.F.A.; Saleh, S.H.; Elsaeed, W.F.; Elshafie, M.A.; Sherief, L.M.; Esh, A.M.H. Serum trace elements in obese Egyptian children: A case-control study. Ital. J. Pediatr. 2014, 40, 20. [CrossRef] [PubMed]

96. El-Mazary, A.-A.M.; Abdel-Aziz, R.A.; Mahmoud, R.A.; El-Said, M.A.; Mohammed, N.R. Correlations between maternal and neonatal serum selenium levels in full term neonates with hypoxic ischemic encephalopathy. Ital. J. Pediatr. 2015, 41, 83. [CrossRef] [PubMed]

97. Qatar General Electricity \& Water Corporation (Kahramaa). Overview on: Kahramaa Drinking Water Quality Requirement; Kahramaa Publications: Doha, Qatar, 2014.

98. Rowell, C.; Kuiper, N.; Al-Saad, K.; Nriagu, J.; Shomar, B. A market basket survey of As, Zn and Se in rice imports in Qatar: Health implications. Food Chem. Toxicol. Int. J. Publ. Br. Ind. Biol. Res. Assoc. 2014, 70, 33-39. [CrossRef]

(C) 2019 by the authors. Licensee MDPI, Basel, Switzerland. This article is an open access article distributed under the terms and conditions of the Creative Commons Attribution (CC BY) license (http://creativecommons.org/licenses/by/4.0/). 